Turkish Online Journal of Qualitative Inquiry (TOJQI)

Volume 12, Issue 1, January 2021: 24-55

DOI: $10.17569 /$ tojqi.793524

Research Article

\title{
Evaluation of Learning Stations on Earth Science Concepts by Gifted Students: Bursa PUYED Example ${ }^{1}$
}

\author{
Osman Elmas ${ }^{2}$, Nermin Bulunuz ${ }^{3}$
}

\begin{abstract}
The purpose of this study is to assess effects of science lessons about earth sciences supported with learning stations on gifted students. The study was conducted in Gifted Children Association (PUYED) with four gifted fifth grade students. The students visited three stations. Semi-structured interviews, science journals and student answers to questions of instructions were used as data collection tools. An action research was used as a research design. Findings gathered from the journals revealed that students had general knowledge about earthquakes, geological faults, and volcanoes prior to station visits. They were observed to explain concepts like tectonic plate movements, how earthquakes occur and mountain-earthquake relationship elaborately. After stations, students were able to make inferences by interpreting data and establish model-reality connection. Students expressed in the interviews their desire to learn scientific concepts with learning stations in their own schools. Using learning stations in their science teaching programs is strongly recommended.
\end{abstract}

Keywords: Gifted children, science education, learning stations, earth science.

\footnotetext{
${ }^{1}$ The ethical committee permission is not required in this study since the data were gathered before 2020 .

${ }^{2}$ Teacher, Bursa Yenişehir Köprühisar Atatürk Secondary School, osmanelmas01@gmail.com, ORCID ID: 0000-0002-0849-694X

${ }^{3}$ Assoc.Prof.Dr., Bursa Uludağ University, Faculty of Education, Department of Mathematics and Science Education,nbulunuz@uludag.edu.tr, ORCID ID: 0000-0001-7891-0379

Received: 15.09.2020, Accepted: 07.01.2021
} 


\title{
Yer Bilimleri Kavramları Hakkındaki Öğrenme İstasyonlarının Üstün Yetenekli Öğrenciler Açısından Değerlendirilmesi: Bursa PÜYED Örneği
}

\begin{abstract}
Öz
$\mathrm{Bu}$ çalışmanın amacı yer bilimleri kavramları hakkındaki öğrenme istasyonları ile desteklenen fen dersini üstün yetenekli öğrenciler açısından değerlendirmektir. Araştırma, beşinci sınıfta öğrenim gören dört üstün yetenekli öğrenci ile Bursa Potansiyel Üstün Yetenekliler Derneği (PÜYED)'nde gerçekleştirilmiştir. Öğrenme istasyonları ziyareti sonrası öğrencilerle yapılan yarı yapılandırılmış görüşmeler, yer bilimleri günlükleri ve istasyonların yönergelerinde yer alan sorulara verilen cevaplar veri toplama araçları olarak kullanılmış ve veriler betimsel olarak analiz edilmiştir. Araştırma deseni olarak aksiyon araştırması yaklaşım kullanılmıştır. İstasyonları ziyaretleri öncesi öğrencilerin günlüklerinde genel olarak deprem, fay ve yanardağ gibi kavramlardan bahsettikleri görülmüştür. İstasyonları ziyaretler ettikten sonra ise öğrencilerin günlüklerinde levhaların hareketleri, depremlerin nasıl oluştuğu ve dağların oluşumunun depremle ilişkisi gibi kavramlara daha detaylı biçimde değindikleri görülmüştür. Öğrencilerin öğrenme istasyonlarını ziyaretleri sonrasında verileri yorumlayarak sonuç çıkarabildikleri ve model-gerçek ilişkisini kurabildikleri görülmüştür. Yapılan görüşmelerde öğrencilerin istasyonlar hakkındaki görüşlerinin olumlu olduğu tespit edilmiştir. Öğrenciler görüşmelere verdikleri cevaplarda kendi okullarındaki fen derslerinde de kavramları öğrenme istasyonları ile öğrenmek istediklerini ifade etmişlerdir. Öğrenme istasyonlarının üstün yetenekli öğrencilere uygulanacak fen dersi öğretim programlarında etkin olarak kullanılması önerilmektedir.
\end{abstract}

Anahtar Sözcükler: Üstün yetenekliler, fen eğitimi, ögrenme istasyonu, yer bilimleri. 


\section{Introduction}

When the studies conducted worldwide are examined, it is seen that the concept of giftedness has many definitions. This shows that the concept of "giftedness" does not have a universal definition, but is generally understood worldwide. Renzulli (1978), while defining giftedness, stated three different criteria in talent, creativity and motivation in a general or specific area and stated that they are intertwined. Similarly, Heller (1996) listed the skills that gifted students should have: intelligence, creativity, and social skills. In addition to the definitions of "gifted student" in world this concept is defined in different ways in many studies conducted in this field in our country. For example, when defining gifted individuals private, academic, has meant individuals performing at a high level compared to other individuals in the age groups in some areas such as intelligence and creativity (Bilgiç, Taştan, Kurukaya, Kaya, Avonoğlu, \& Topal, 2013). Sak (2014) stated that gifted students learn quickly, their creativity, and imagination are at a high level. Also, according to the directives of Turkish Science and Art Centers (MEB, 2015) intelligence refers to the "student who shows a high level of performance compared to his peers in creativity, art, leadership capacity or special academic fields. In addition, Sternberg and Zhang (1995) developed the Pentagon theory, which states that an individual must meet five criteria such as extraordinary, productivity, value, rarity, and evidence in order to be gifted. According to him, in order to evaluate the individual as gifted; it is much better than its peers in any field (excellence), it has a superior ability, in a rare feature among its peers, it is productive about its goodness, its abilities can be determined by valid tests and its skills in culture it must have criteria (excellence, rarity, productivity, demonstrability, and value criteria). Gagne (2000), on the other hand, in the theory of "Differential Giftedness and Giftedness (DGMT)" says that it comes from birth (it is a gift) and that it expresses mental capacity. According to him, giftedness is the manifestation of this advanced mental capacity in a specific area (cited in Sak, 2017). One of these areas is the field of science. However, regardless of the definition of giftedness, it is a fact that these students should be supported in areas where they are better than their peers. Because gifted students have special needs, and if these needs are not met, they become blind and lose their interest.: Because gifted students need special education support due to the above mentioned characteristics; if they are not supported they may lose their interest (Renzulli \& Reis, 1985; Çepni, Gökdere,0 \& Küçük, 2002). 
There are differentiation strategies in the literature to support gifted students. These are enrichment, acceleration, and grouping strategies. According to Ülger (2020)'s report, differentiation ensures that each student's learning style, interests and abilities are different, and the learning experience is organized according to these characteristics (Tomlinson, 1999). This differentiation can take place in the content, process, environment and product dimensions of the teaching. Among these strategies, especially enrichment and acceleration strategies come to the fore (Türkman, 2017). According to Robert (2005), enrichment is planning education in different ways to meet the educational needs of students. On the other hand, acceleration enables gifted students to receive an education at a higher level than their current education level (Kanl1, 2011). As an educational strategy, enrichment allows gifted students to look at events and concepts from a different perspective, question them (critical thinking); enable them to develop creative solutions to situations or problems and develop skills such as teamwork (VanTassel-Baska \& Brown, 2007). Below are the curriculum models using these training strategies. "Curriculum models provide theoretical frameworks that form the basis for the development and planning of learning activities in the education of the gifted." (Sak, 2017: 171).

Many curriculum models have also been developed, which aim to realize the potential of gifted students. Some of these models are: Maker Model, Parallel Curriculum Model, Curriculum Narrowing Model, Integrated Curriculum Model, Grid Model and RAP Curriculum Model. Akkaş and Tortop (2015) compared curriculum differentiation models with each other in their research including the above-mentioned curriculum models. As a result of their research, they determined that acceleration and enrichment strategies can be used alone or together.

The curriculum model used in this research is the Parallel Curriculum Model. Parallel Curriculum Model consists of general curriculum, links curriculum, applications curriculum, and awareness curriculum. This Parallel Curriculum Model curriculum model that provides a framework for the realization of teaching (Tomlinson, Kaplan, Renzulli, Purcell, Leppien, \& Burns, 2002). It also enables the education given to gifted students to develop parallel curricula based on the learning objectives included in the national education system (general curriculum) (Sak, 2017). For example; based on the learning objectives of the unit " Sun Earth and Moon " (Ministry of National Education, 2018) in the 5th grade "Earth and the Universe" subject area, students gain experience in the field by making applications on the subject (experimenting, 
modeling) with the awareness curriculum and they can be provided with a metacognition about the field. Parallel curriculum components can be used alone or together in Parallel Curriculum Model (Tomlinson, Kaplan, Renzulli, Purcell, Leppien, \& Burns, 2002). The reasons behind the emergence of this curriculum model is that it is based on the assumptions that gifted students encounter difficult and complex problems and that they know themselves and specialize in the area they will head towards (Tortop, 2015). In the development of curriculum models, gifted student characteristics are always taken into account.

There are some distinctive features of gifted students in science education. The courses developed within the scope of the research are planned by taking these features into consideration. These features are possible or can be developed in gifted students participating in the study. Some of the features introduced by Stepanek (1999), Gilbert (2002) and Key Stage 3 National Standards (2003a) are given below (as cited in Newberry \& Gilbert, 2007):

- They show great interest in discovering scientific facts,

- They have a tendency to observe and ask questions,

- They can easily learn new ideas,

- Quickly establish connections between the facts and concepts they have learned, establish connections between scientific concepts and observed phenomena,

- Go beyond the given knowledge, move ideas from the context they learn to unknown contexts,

- Quickly understand models and theories in new situations and use them to explain facts and,

- Generate models and shape them mathematically.

- They suggest different strategies for testing predictions.

- They can reflect their own thoughts or learning.

Science lesson is a field attracting the interest of gifted students and challenging them to utilize their mind at maximum capacity (VanTassel-Baska, 2006). Science teachers are not only expected to provide appropriate environment for gifted students, but also to construct lessons according to their readiness levels and background knowledge (Tomlinson \& Strickland, 2005). In order to develop the needed skills in gifted students, it is of high priority that the activities are meticulously planned, original and extraordinary (White, 2005). 
According to VanTassel-Baska and Stambaugh (2006), there should be seven important elements in the education programs to be developed for gifted students. These elements are; 1) developing an understanding of scientific concepts; 2) developing scientific research skills in collaborative environments; 3) developing a knowledge base in the field of science; 4) developing interdisciplinary interactions; 5) developing real-life problem research skills; and 6) scientific to improve thinking skills" (cited in Erdoğan \& Kahveci, 2015). Parallel Curriculum Model is one of the curriculum models bearing these elements (Erdoğan \& Kahveci, 2015). In this research, based on these factors, the subject of earth sciences, which provides interdisciplinary interaction with real life problems (earthquakes), was selected. In Earth sciences 5th grade Science course, the subject area of "Earth and Universe" is included in the unit of "Getting to Know Our Planet" in our curriculum (MEB, 2018). In this study, the activities were tried to be original and extraordinary with earth sciences dealing with real world problems (Bralower, Feiss, \& Manduca, 2008; Michigan State Board of Education, 2006).

According to Manduca (2008), there are some problems awaiting the next century. Global warming caused by greenhouse gases released into the atmosphere, the exhaustion of fossil fuels and water scarcity can be shown at the beginning of these problems (as cited in, Misir, Muğlaloğlu \& Dal, 2017). In order to reduce or eliminate these problems, the students who are given earth science education; The best and in-depth understanding of earth science subjects should be ensured (The Geological Society of America, 2011; Bralower, Feiss, \& Manduca, 2008). Because earth sciences are about the layers of the earth, volcanoes, atmosphere, rocks, and etc. (McLelland, 2011). According to Kastens and Manduca (2012), if students learn earth sciences well, they can have an idea in solving possible problems. As these problems gradually increase every day, they can only be solved by understanding earth sciences better. Methods to optimally teach earth sciences to gifted students should be identified as these children are considered to be the future experts of producing and utilizing new technology (Erdoğan \& Kahveci, 2017). Viable solutions on such essential matters can only be possible by proper education.

There are interdisciplinary relationships in the content of earth sciences (Clinton, 2010). These disciplines such as physics, chemistry and biology also enable the use of earth sciences in science classes. According to Kastens and Manduca (2012), understanding earth sciences is possible with science literacy (cited in Akçay, 2017). OECD (2019) argues that deal with 
scientific issues and scientific literacy is defined as the ability to think on these issues (PISA 2018 Turkey Preliminary Report, 2019). In order for the individual to be a science literate, "explaining the facts scientifically, designing and evaluating a scientific inquiry method; data and interpret scientific findings "(OECD, 2019; cited in Pisa 2018 Turkey Preliminary Report, 2019, pp. 80) are required to carry their skills. MEB (2018) also explains the aim of the science curriculum as raising science literate individuals. In this context, one of the key concepts of raising science literate individuals is "How do we teach?" There are teaching techniques that answer the question. According to Çepni and Çil (2016), teaching techniques are the transformation of the chosen teaching method into practice. Regardless of the curriculum applied, a teaching technique should be chosen in accordance with the teaching objectives to be achieved.

In this current study, the hands-on learning stations technique was used. Benek (2012) defines this method as a technique where children are responsible for their own learning, a technique supporting peer learning through group work, actively engaging students with the help of constructivist approach and the theory of multiple intelligences. To apply this method, the teacher forms accurate learning stations for the given subject in the classroom, laboratory or workshop. These learning areas are called "learning stations" or "station centers" (Fraling, 1982). Students conduct some activities at each station for a specific period of time then proceed to the next one (Jarrett, 2010). Each learning station has a separate purpose which the students try to reach. Students are guided by the instructions of each station (Bulunuz \& Jarrett, 2009).

In the learning station method, students take responsibilities, actively participate in the activities and socialize. While facilitating peer learning, this technique also improves communication skills. Moreover, working in small groups at the stations enables positive behaviors such as better learning, a longer span of keeping the knowledge in mind and being more in harmony with the environment (Beckman, 1990; Bulunuz, \& Jarrett, 2009; Bulunuz, \& Jarrett, 2010; Cohen, 1994). In addition to hands-on learning station technique, modeling is frequently used in science lessons. The aim of teaching through modeling in science is to concretize and demonstrate and explain scientific concepts because they are very abstract or in dimensions that cannot be exhibited in the classroom (Çepni \& Çil, 2016). 
Modeling technique activates cause-effect relationships and reasoning skills to create a mental model (Gobert \& Pallant, 2004; Seel, 2001). In this research, concepts such as earthquakes, volcanoes and layers of the earth, which are among the topics of earth sciences, have been also studied by modeling.

The general purpose of this study is to assess the "science" lesson about earth science concepts applying learning stations for gifted students at the fifth grade registered at "Bursa Gifted Children Association" (PUYED). This research sought answers for the following questions:

1. What knowledge do the gifted students have before and after visiting the learning stations about earth science concepts?

2. What are the answers of the gifted students for the questions in the learning station instructions?

3. What are the views of gifted students regarding the learning stations about earth science concepts?

\section{Methodology}

\section{Research Design}

Qualitative research method (Creswell, 1994) was used in this research. Specifically, the action research method, which is a method used especially by teachers working in the field, was used (Çepni, 2014). According to Clement and Vandenberghe (2000), this method enables teachers not only to be practitioners but also to switch from passive to active position to innovations in education by making researches (cited in Çepni, 2014). Collins and Spiegel (2001) define this method as the "Researcher Teacher Model"; it examines in four stages: 1) determining the problem, 2) planning for the solution of the problem, 3) implementing the plans, and 4) evaluation (cited in Çepni, 2014). The science teacher, who is the first author of the study, followed the steps put forward by Collins and Spiegel (2001) in this study.

The science teacher working in the field applied and tried to evaluate the problem of "How can they learn better" for his gifted students with a planned study. In this way, the education given to gifted students, the effects of the curriculum models used, when supported by appropriate teaching techniques, were investigated by consulting students' opinions. For this purpose, semi- 
structured interviews were used to get the opinions of the students as a result of the application, diaries to evaluate the effectiveness of the study during and after the application, and learning station assessment questions were used.

\section{Gifted Children Association: (PUYED)}

This research was conducted in 2017-2018 Fall semester in Bursa at the "Gifted Children Association" (PUYED) where gifted children receive education. This association accepts gifted students from pre-school (age 5) up to 7th grade (age 12). Students who score enough (bright level on the normal distribution curve) from the standardized IQ tests in our country are included in the education program of the association. After a four-week integration process, the students are evaluated in a meeting which PUYED teachers, parents and the student attend. In case the evaluation result is affirmative, the student gets to stay in the program until the end of the semester. All students registered at PUYED take the lessons: 1) Art, 2) Computer, 3) Science and 4) Critical Thinking and lesson content varies based on class level. Each lesson is one hour a week and all lessons are held on Saturdays. This research was conducted in the "Science" lesson.

\section{Participants}

The participants were four gifted fifth grade students. The learning stations were organized by the science teacher conducting the "Science" lessons at PUYED. The first author of this paper was also the "science teacher" of the participant students. The researcher (Science Teacher) has been teaching with gifted students by enriching, accelerating, or differentiating the science course at PUYED for a year. This researcher also acted as a "guide" during the students' visits at the stations.

\section{Gifted students}

Four gifted fifth grade students participated in this research. Each student was given a code name within the scope of the study and these code names were used in this paper instead of their actual names. General information regarding the participating students is given below: 
Eymen is an 11-year-old fifth grader. He was administered WISC-R intelligence test in 2016. $\mathrm{He}$ is currently attending a private secondary school in Bursa. He is a reticent, silent person, albeit extremely energetic and physically active. He usually swings while sitting or walks when he is speaking. He is more interested in activity parts of lessons. He has an enthusiastic nature. He uses Turkish properly. While being polite and respectful, he asks a lot of questions. He responds with original answers to the questions he is asked. Experiments make him happy. He likes to be active during the lesson or the experiment. Once the topic in the lesson is not intriguing for him, he starts playing with the materials in the class he deems interesting. He wishes to conduct experiments during entire lessons. He prefers individual work rather than group work.

Berrak is an 11-year-old fifth grader. She was administered CAS intelligence test in 2016. She is currently attending a private secondary school in Bursa. She is a curious, highly concentrated student actively answering questions. Observations showed that she interprets questions in her own way, strictly follows instructions, asks questions when something is not clear and easily expresses herself. She likes to write, uses critical thinking for problem solving. She is actively engaging in individual assignments yet prefers to remain out of the limelight in group work.

Tuğba is an 11-year-old fifth grader. She was administered CAS intelligence test in 2016. She is currently attending a public school in Bursa. She has a good sense of humor. She likes to paint. She has a serene nature easily adapting to different environments. She follows instructions. She likes to ask questions and has good communication with her friends. She participates in the activities in science lessons enthusiastically. She enjoys learning new stuff and reflects these in her daily life. If she thinks it contributes her, she does not refrain from writing.

Deniz is an 11-year-old fifth grader. She was administered WISC-R intelligence test in 2016. She is currently attending a public school. She has a very quiet, calm, naïve nature. She follows instructions. Her communication with her friends is good. It may take her time to mingle with the group though. In case there are friends she gets on well, she engages actively in the group. Being cheerful in science lessons, she enjoys learning new stuff. She does not refrain from expressing her emotions and opinions during class. She actively answers the questions and likes to leave the class with a product. 
Table 1 below shows gender, school type and intelligence scales used for diagnosis of the participating students.

Table 1

Student Introduction Summary

\begin{tabular}{llll}
\hline Name & Gender & School Type & Intelligence Scale Used for Diagnosis \\
\hline Eymen & M & Private School & WISC-R \\
Berrak & F & Private School & CAS \\
Tuğba & F & Public School & CAS \\
Deniz & F & Public School & WISC-R \\
\hline
\end{tabular}

\section{Acquiring Ethical Consent from Parents}

A parental consent form was prepared by the Chairwoman of the Board of PUYED and was presented to the parents for approval one week prior to the activity. The ethical consent document included information of the topic of learning stations, purpose of the activity, person or institution to conduct the activity, name of the supervisor, contact address, date and time. Parents signing this document accepted their children to voluntarily take part in the study and that findings would be used for scientific purposes.

According to the TR DİIIN Journal Evaluation Criteria updated for 2020, the ethical committee permission is not obligatorily required in this study to be published in a journal indexed by TR DİIIN since the data were gathered before 2020 .

\section{Preparing the Learning Stations}

The subject of "Destructive Natural Phenomena" is included in the fifth grade Science Curriculum (MEB, 2017). This is the subject that is intended to be differentiated using the Parallel curriculum model. The reason for choosing this subject is to raise awareness of gifted students due to the increasing global problems. The acquisitions have been taken from the national curriculum on the subject and these gains have been differentiated in a way that 
enables students to grapple with difficult problems. This stage constitutes the general curriculum dimension of Parallel Curriculum Model. The fields of earth science, engineering and chemistry were selected for the curriculum of links aimed at establishing a relationship with other disciplines. New achievements are determined by making connections between these disciplines and the subject area. In the next stage, the applications curriculum, gains are written for students to practice similar to the experiences of experts in the specified disciplines. In this way, gifted students will gain familiarity and experience in the specified fields of earth sciences, engineering and chemistry.

After the differentiation of the outcomes, the teaching plan was created by determining how the objectives will be transferred to the students, how much time will be allocated, and what criteria will be evaluated. Scientific process skills, life skills, and engineering design skills in MEB Science Curriculum (2018) in the process of recreating and differentiating the gains; Mentioned in the preamble to distinguish the characteristics of gifted students in science fields (page number) and PISA 2018 Report of Turkey (2019) it has been utilized in areas where science literacy skills. One of the important aspects of the parallel curriculum model is the use of thinking skills and creativity skills in the teaching process (Tortop, 2015)

Three learning stations were designed in this research: 1) How did the mountains form? 2) Let's make a volcano model with soil! and 3) How do earthquakes occur? The first and second stations were adapted from English to Turkish from the doctoral dissertation of the second author. The other learning station used in the study and related to earthquakes was created by the first author. The station about earthquakes was based on related achievements of the curriculum and the "they understand scientific concepts in depth" (Gould, Weeks \& Evans, 2003) characteristic of gifted students. In other words, achievements prepared for average students in the curriculum were elaborated for gifted students. After the learning stations and their instructions were prepared, parents of the students were contacted for ethical consent. Students were informed about the activity one week prior to it in order to have them psychologically ready. Within the same week, materials required for the stations were supplied, these were placed together with the instructions on to the tables where the activities were to be conducted and the classroom environment was prepared for the activity. 


\section{Application of the Learning Stations}

Names and order of the learning stations used in the research are as follows:

1st Station - How did the mountains form?

2nd Station - Let's make a volcano model with soil!

3rd Station - How do earthquakes occur?

Before the activity, teacher gathered to make necessary arrangements and checked the tables of the experiment setups. As four students participated in the research but only three learning stations were available, first and second stations were given two students each. After completing both stations, all students proceeded to the third station and conducted the activity together. Students spent approximately 20 minutes at each station.

\section{Data Collection Tools}

Three data collection tools were employed in this research: 1) Post-activity interviews with the students; 2) Earth science journal and 3) Questions of the instructions of learning stations. Detailed information regarding these data collection tools is presented below.

\section{Post-activity interviews with the students}

Semi-structured interview technique was used in order to get feedback from the gifted students about the learning stations, to find out their opinions and to determine whether the learning target was reached. This interview, in which students took part individually, was conducted in the meeting room at PUYED immediately after the activity.

The interview questions consist of open ended questions, which were previously used in a study of the second author, prepared for assessing student feelings and opinions after the learning station. The reason for using semi-structured interview questions was to prevent unclear answers or students getting nervous and to obtain more illuminating answers. Each individual interview with four gifted students lasted around 4-7 minutes and was recorded on a mobile phone. Prior to the interview, students were informed on the purpose of the research and how the interview recordings were going to be used. 
Computerized interview recordings were reviewed by the first author repeatedly and transferred to a word processor program. Transferred data includes the utterances of both the interviewer and the interviewee. Answers to the interview questions were initially separated with color codes. The color codes were determined according to the properties of the given answers. The third research question was taken into consideration while the student responses were divided into themes. The answers given to the questions aiming to get the students' opinions about the lessons were listed from the most spoken theme to the least spoken theme (Table 6).

Received answers were divided into themes and tabulated. This table presents all answers according to the themes. The "frequency" in Table 6 expresses how many responses received from students regarding the theme in question.

\section{Earth science journal}

The earth science journal was prepared so as to reveal what students knew before, what they observed during the activity, what they learned after the activity and to determine their questions in case they had any. Separated in four columns, these one-page journals contain the titles: 1) My Earth Science Vocabulary; 2) My Observations; 3) What I Learned; and 4) My Questions.

This data collection tool was distributed among the students right before the learning station activity started and they were asked to fill in the "My Earth Science Vocabulary" part at first. The teacher asked the students to write everything they know about earth sciences. They were reminded to fill in the other parts during the activity. The purpose in this was to compare what the students knew before with what they learned during the activity.

\section{Answers to the questions of the instructions of learning stations}

Three separate instructions were prepared for the three learning stations used in this research and below each instruction a comprehensive question considering the gifted students' class level was written to determine whether the concept of the station was understood by the 
students. The purpose of asking single but comprehensive questions was to occupy the students' minds enough in order to prevent the students from getting bored while answering the questions. The students were reminded to answer the question once the activity in each station was completed. They were given a blank paper and sufficient time.

\section{Findings}

\section{Findings Regarding the First Research Question}

The first research question of this study is: "What knowledge do the gifted students have before and after visiting the learning stations about earth science concepts?" To answer this question, the students were given earth science journals. The journals have three parts. The students were asked to write: 1) What concepts they know before the activity; 2) Their observation results; and 3) What concepts they learned after the stations. The journal notes of the students are presented below in Table 2 .

Table 2

Answers the Students Gave in Earth Science Journals

\begin{tabular}{|c|c|c|c|}
\hline $\begin{array}{l}\text { Students } \\
\text { Name }\end{array}$ & $\begin{array}{l}\text { Concepts I Knew Before } \\
\text { Stations }\end{array}$ & My Observations & $\begin{array}{lll}\text { Concepts I Learned After } \\
\text { Stations }\end{array}$ \\
\hline Deniz & $\begin{array}{l}\text { Fault line, mountains, earth } \\
\text { crust, volcanoes }\end{array}$ & How earthquakes occur & $\begin{array}{l}\text { - How earthquakes occur } \\
\text { - How earth crust overlaps } \\
\text { and how mountains are } \\
\text { formed } \\
\text { - How volcanoes form in } \\
\text { detail }\end{array}$ \\
\hline Eymen & Earthquake & People get scared & $\begin{array}{l}\text { - } \begin{array}{l}\text { Earthquakes occur by } \\
\text { tectonic } \\
\text { overlapping }\end{array} \\
\text { plates }\end{array}$ \\
\hline Tuğba & $\begin{array}{l}\text { Lava, earthquake, volcano, } \\
\text { temperature, } \\
\text { earthquake }\end{array}$ & $\begin{array}{l}\text { How volcanoes and mountains } \\
\text { form }\end{array}$ & $\begin{array}{l}\text { - Mountains form by } \\
\text { earthquakes } \\
\text { - Volcanoes explode due } \\
\text { to earthquake induced } \\
\text { lava eruption }\end{array}$ \\
\hline Berrak & Seism & $\begin{array}{l}\text { People panic. Earth shakes. } \\
\text { We may be buried under } \\
\text { wreckage }\end{array}$ & $\begin{array}{l}\text { - Earthquakes occur when } \\
\text { strata of earth crust } \\
\text { rupture }\end{array}$ \\
\hline
\end{tabular}

As seen above in Table 2, some students mentioned concepts such as earthquake, fault line and volcano in the "Concepts I Knew Before Stations" part in the journal, whereas they described 
concepts such as tectonic plate movements, how earthquakes occur and the relation of mountains and earthquakes in detail in the "Concepts I Learned After Station" part. But not all students gave details. For example, while Deniz and Eymen only said what they learned, Berrak and Tuğba explained what they learned in detail.

For example, Berrak, who only knew the concept "seism" about earthquakes, answered in the concepts I learned after stations part as: "I learned that earthquakes occur when strata of earth crust rupture". It was observed that Tuğba, like his other friends, detailed the concepts he had about the concepts of earth sciences after his visit to the stations. After visiting the stations about how mountains and volcanoes were formed, Tuğba was observed to associate the mountain-volcano couple with earthquakes. However, the fact that Deniz and Eymen only said what they learned but did not elaborate on what they learned made us think that they could not reflect their knowledge to YBG or learn the subject. Looking at Table 3, Table 4, and Table 5, it is seen that in the answers given to the station questions, Deniz and Eymen gave more clues and explanations about what they learned.

\section{Findings Regarding the Second Research Question}

The second research question in this study is: "What are the answers of the gifted students for the questions in the learning station instructions?" In this context each station instruction included one question which the students answered after completing each station. Questions in the instructions in the given order and students answers are presented below.

Table 3

Answers Given to the Questions in the First Station

\begin{tabular}{ll}
\hline $\begin{array}{l}\text { Student } \\
\text { Name/Question }\end{array}$ & What kind of relationship is there between the formation of mountains and earthquakes? \\
\hline Deniz & Volease explain. \\
& mountain-like dough is the fault line. \\
Eymen & Strata overlap when earthquakes occur and mountains are formed. \\
Tuğba & Formation of mountains: There is a connection between mountains and earthquakes. \\
& When there is an earthquake, mountains move, or even form. \\
Berrak & $\begin{array}{l}\text { Earthquakes cause strata to rupture. These ruptures push the tectonic plates and new } \\
\text { plates (strata) appear on the surface. }\end{array}$ \\
\hline
\end{tabular}


Table 3, above, shows the question from the learning station named "How did the mountains form?" and corresponding student answers. In this learning station, students pushed two different strata models, which they formed with play dough, towards each other and observed the result. Given answers indicate students establishing model-reality connection. Deniz's answer; "Volcanic eruptions may lead to earthquakes. That is the relationship." to the question; "What kind of relationship is there between the formation of mountains and earthquakes? Please explain" is a good example for establishing this connection.

The answers also proclaim that the students are able to realize the connection between earthquakes and mountains. As an example, Berrak explains the formation of mountains with her answer; "Earthquakes cause strata to rupture. These ruptures push the tectonic plates and new plates (strata) appear on the surface." Eymen responded with a similar answer to Berrak. Tuğba mentioned that mountains move or form when earthquakes occur, after she expressed that there is a connection between mountains and earthquakes.

Table 4

Answers Given to the Questions in the Second Station

\begin{tabular}{ll}
\hline $\begin{array}{l}\text { Student } \\
\text { Name/Question }\end{array}$ & Please explain how volcanoes form, based on your observations. \\
\hline Deniz & I think mountains erupt and become volcanoes. \\
Eymen & Volcanic eruptions are caused by lava in magma reaching the surface. \\
Tuğba & Earthquakes cause lava to erupt which leads to volcanoes to form. \\
Berrak & $\begin{array}{l}\text { Acid-like (vinegar) stuff inside the volcano comes together with the magma stratum and } \\
\text { erupts. }\end{array}$ \\
\hline
\end{tabular}

Table 4, above, shows the question from the learning station named "Let's make a volcano model with soil!" and corresponding student answers. Students observed in this learning station the volcano model they structured with chemical compounds. It was observed that students were able to establish model-reality connection just like in the previous station. As seen from the answers to the question "Please explain how volcanoes form, based on your observations.", students associated volcanoes with magma and explained this concept through earthquakes. For example, with her answer "Earthquakes cause lava to erupt which leads to volcanoes to form.", Tuğba deduced that earthquakes cause volcano eruptions. 
Table 5

Answers Given to the Questions in the Third Station

\begin{tabular}{ll}
\hline $\begin{array}{l}\text { Student } \\
\text { Name/Question }\end{array}$ & Please explain how seismic waves form, based on your observations. \\
\hline Deniz & The ground shaking causes seismic waves. This is the reason of earthquakes. \\
Eymen & Ground shaking. \\
Tuğba & Earthquake is two rocks shaking. And then one rock gets on top of the other. \\
Berrak & Earth shakes due to underground strata rupturing. This is called earthquake. \\
\hline
\end{tabular}

Table 5, above, shows the question from the learning station named "How do earthquakes occur?" and corresponding student answers. The most comprehensive answer to this question came from Berrak: "Earth shakes due to underground strata rupturing. This is called earthquake." The other three students explained seismic waves as a result of ground shaking. For example, Deniz explained the concept as: "The ground shaking causes seismic waves. This is the reason of earthquakes."

\section{Findings Regarding the Third Research Question}

The third research question in this study is: "What are the views of gifted students regarding the learning stations about earth science concepts?" Data obtained from the interviews with the four students participating in the research was analyzed qualitatively through thematic analysis. Data including sub-themes, frequencies and sample sentences are summarized in Table 6 below. The frequencies were obtained by giving answers to different questions containing the same theme. For example, it is seen that 14 answers were given on the subject of the theme "Lesson with learning stations being entertaining or nice". 
Table 6

Thematic Analysis Results of Interview Data

\begin{tabular}{|c|c|c|}
\hline Sub-Theme & Frequency & Sample Sentence \\
\hline Lesson with learning stations being entertaining or nice & 14 & $\begin{array}{l}\text { "The lesson is more fun." (Eymen) } \\
\text { "I can't decide on how to answer the question -Which was the most effective station?- } \\
\text { They were all nice." (Deniz) } \\
\text { "I liked the volcano activity the most because it was an experiment with eruption." (Tuğba) }\end{array}$ \\
\hline Cognitive assessment regarding learning stations & 14 & $\begin{array}{l}\text { "If buildings are built durable, they won’t collapse." (Berrak) } \\
\text { "The red liquid at the volcano station represented lava." (Deniz) } \\
\text { "Volcanic eruptions are caused by lava in magma reaching the surface." (Eymen) }\end{array}$ \\
\hline Lesson with learning stations being efficient in learning the topic & 9 & $\begin{array}{l}\text { "The most effective and most informative stations are volcanoes then marshmallows } \\
\text { (earthquakes) and lastly mountains." (Tuğba) } \\
\text { "Learning stations are effective for me to learn a topic." (Berrak) } \\
\text { "We learned and experimented how mountains form." (Deniz) }\end{array}$ \\
\hline No or few experiments being conducted in science lessons & 9 & $\begin{array}{l}\text { "I don’t need to sit at my desk for forty minutes in this lesson." (Tuğba) } \\
\text { "We sit and listen to the teacher at school. We write at school. Half of the lesson is wasted } \\
\text { with complaints." (Tuğba) } \\
\text { "We don't have a lesson in my school involving learning stations" (Berrak) } \\
\text { "They teach us things that we can understand at my school, but here we learn more stuff } \\
\text { and more elaborately." (Deniz) }\end{array}$ \\
\hline The wish to conduct science lessons with station method & 7 & $\begin{array}{l}\text { "I would never want the lesson to end if they conducted lessons with station activities at } \\
\text { my school." (Berrak) } \\
\text { "It would be good to conduct science lessons with stations. I would even write a petition to } \\
\text { the school principal to have science lessons every day." (Tugba) } \\
\text { "It would be nice to conduct the science lesson with the station method." (Deniz) }\end{array}$ \\
\hline School - PUYED comparison & 5 & $\begin{array}{l}\text { "We don't get into detail at school. Earthquake and stuff, usually no details." (Deniz) } \\
\text { "When conducting an experiment at school, the teacher never directs us research questions. } \\
\text { He only asks questions, never asks us to write." (Berrak) } \\
\text { "It is beneficial that they ask us questions and want us to write at PUYED." (Berrak) }\end{array}$ \\
\hline
\end{tabular}




\section{Discussion and Conclusion}

\section{Discussion and Conclusion Regarding the First Sub-Problem}

With the help of learning stations prepared suitable for 5th grade gifted students, earth science concepts in science lesson have been diversified and enriched in this research. Earth science journals were employed to identify background knowledge, observations and newly learned concepts of the students.

After the stations, on the other hand, they wrote sentences with inferences. Berrak, for example, was observed to make inferences from the activity by writing in the "Concepts I Learned After Stations" column of the ESJ: "I learned that earthquakes occur when strata of earth crust rupture." One of the skills to develop in gifted students is inference skill (Halkitis, 1990). One of the results obtained from this study is that this skill can be improved provided that an education method is developed according to the characteristics of gifted students. At the same time, it was seen that Tuğba made such an inference by saying, "I learned that volcanoes exploded when the earthquake occurred because the lava inside them exploded". Gifted students making predictions and inferences based on observations or data can be considered as an output of the learning station learning technique. Bekereci, Şimşek, Hamzaoğlu, and Yazıcı (2020), in their study on 7th grade students, concluded that the science lesson taught using the learning station was significantly in favor of the station compared to the lesson taught using the lecture method. The results of criteria such as the use of station technique in the research to facilitate understanding and increase academic success support this study. In addition, from the skills that are aimed to be acquired while organizing learning activities (MEB, 2018; Burns, 1993; OECD, 2019), the skills of seeing relationships (analytical thinking skills; the relationship between earthquake-layers of the earth-volcano), determining the effect-reaction and explaining scientific facts, it is observed that it develops. One of the studies conducted in this context is the study in which Kök and Davasligil (2014) examined the effects of differentiated courses on the spatial skills of gifted students with the Parallel curriculum model. The research concluded that spatial thinking skills developed positively. Likewise, the answers given to YBG in this study show that gifted students envision and shape the concepts of earth sciences in their minds. 
Examining the concepts the students knew before visiting the stations revealed that they roughly mentioned the concepts, however, were unable to explain them in detail. However, the data obtained from the data collection tools used in other research questions show that students gave more detailed answers.

\section{Discussion and Conclusion Regarding the Second Sub-Problem}

So as to determine whether the activities with the learning stations fulfilled the purpose, the questions in the instructions were asked the students. The second research question was answered by the analysis of these answers.

The answers to the question "What kind of relationship is there between the formation of mountains and earthquakes? Please explain." from the instructions of the first learning station "How did mountains form?" were analyzed. This analysis showed that the students were able to explain the relationship correctly and to make inferences by interpreting data. In a study conducted by Güneş (2009), which includes similar results, a positive and significant result was found in the knowledge level of the students by using the station technique. In addition, studies investigating the effect of science lessons taught using station technique on academic achievement show that the academic success criterion has increased positively (Benek, 2012; Çakmak, 2018; Erdağı, 2014; Koca, 2018).

At the second station "Let's make a volcano model with soil!" the question "Please explain how volcanoes form, based on your observations." was asked. Examining the answers revealed that the students were able to explain how volcanoes form and to name the real-world counterparts of the material used in the experiment. At the third learning station "How do earthquakes occur?" the question "Please explain how seismic waves form, based on your observations." was asked. One of the students gave a short answer, whereas the others wrote more comprehensive answers. In one of the detailed answers the student named the tectonic plates rocks and that the earthquake was due to these rocks' movement. Another student stated that the earth was shaking as a result of rupturing strata. 
In these results, it can be said that gifted students quickly understand modeling, establish a relationship with real life, and develop previous models in their minds. A similar study in which modeling activities were used and the 6th grade students developed mental models as a result of the research supports this result (Arslan \& Doğru, 2014). As mentioned above, the students' responses to the questions at the stations can be among the positive results of science lessons that are differentiated by using learning modeling and station technique, such as the development of their skills such as interpreting data from scientific process skills, reaching results based on data and seeing relationships.

Analysis of the student answers to the questions in the station instructions showed that the gifted students gained more detailed and comprehensive knowledge regarding earthquakes, mountains and volcanoes, after the activity. As the knowledge the students had before the activity and findings from the interviews exhibit, the things they learned at school were very limited and were taught with an unsatisfying education method. The findings Çelikdelen (2010) obtained from her master's thesis study about determining the difficulties students attending BILSEM (Science and Art Education Centers) face in science and technology lessons in their own schools also support the findings of this research.

\section{Discussion and Conclusion Regarding the Third Sub-Problem}

Semi-structured interviews were conducted with the students at the end of the activity with the purpose of determining the views of the gifted students about the learning stations. Interview data was analyzed thematically. Table 6, including sub-themes and sample sentences, is presented in the "Findings" section.

Fourteen different answers were received about the sub-theme "Lesson with learning stations being entertaining or nice". The students stated that they enjoyed this lesson because they were able to conduct activities or experiments within the scope of learning stations in science lesson. As a matter of fact, the expression "The lesson is more fun." of a student indicates that students enjoy the lesson more and their enthusiasm for learning increases when they are active instead of passive. Erdağı and Önel's (2015) study, in which the students were found to enjoy station activities and to be successful in group work, supports this result. Another example displaying that they enjoyed science lesson with stations is Deniz's answer 'I can't decide. They were all 
nice. " to the question "Which was the most effective station?" As a result of Benek's (2012) study using learning station technique, the fact that 7 th grade students found the lessons enjoyable and beneficial supports the result of this research. Similarly, in the studies of Erdağ1 (2012), Koca (2018) and Çakmak (2018), it was determined that science lessons taught with the learning station technique caused positive attitude developments on students.

The scientific terminology, Eymen and other students used during the interview for their answers to the questions on the cognitive assessment about the learning stations, proves that they learned the concepts. In addition, Deniz's linking the materials used in the modeling experiment with real life shows that the teaching is effective and Parallel Curriculum Model's links curriculum is linked to different disciplines (earth science and chemistry). Parallel Curriculum Model's links curriculum aims to establish analogies between the contents and to gain the ability to see concepts such as experts in the field. It is understood that the students gained these skills from the answers they gave.

Although they study the same topics at their schools, the scantiness of their notes in the "My Earth Science Vocabulary" section and the common student view regarding insufficient lessons at school revealed that activities such as learning stations help them learn topics better. Berrak's answer "They only told us about volcanoes at school but didn't mention how mountains form." from the interview can be given as an example. The sentence makes it clear that they do not get into detail at school and that she learned this topic in depth with the station method.

The sub-theme "Lesson with learning stations being more efficient in learning the topic" shows that students deemed all stations efficient in learning the topic. In addition, Berrak's answer "Learning stations are effective for me to learn a topic." is an example for students seeing the station method as an efficient learning technique.

Analyzing pre and post learning station student cognitive levels shows that students generally understood earth science concepts taught through stations. The fifth graders in the research were able to understand without explanation that surfacing lava from magma lead to volcanic eruptions, buildings can resist earthquakes if built strongly, red liquid in the activity represents lava. Apart from establishing relationships with other disciplines, it is observed that Parallel Curriculum Model has acquired the skills required to be acquired within the scope of the 
applications curriculum. Because, referring to the effects of earthquakes on buildings, students actually encountered the same problems as field experts and developed awareness of these problems.

When all these results are evaluated together, the following results can be reached based on the science course teaching process, which was developed using Parallel Curriculum Model and includes the learning stations technique:

- It is seen that differentiation with the parallel curriculum model causes students to establish interdisciplinary relationships, to establish relationships between concepts, to develop the scientific language they use (Table 6), to develop a positive attitude towards the course, to develop awareness by facing the same problems as field experts and to develop the thinking skills that are desired to be acquired. There are similar studies supporting these results. With the Conn-CEPT project, gifted students were worked on and differentiation was made using Parallel Curriculum Model. It was concluded that the level of satisfaction with the lessons and the relationship between concepts were positively affected by the students who took differentiated teaching (Erdoğan, 2017: 116). In addition, Erdoğan and Kahveci (2015), Özyaprak and Davasligil (2015) concluded that there are positive developments in the attitudes of gifted students towards the lesson with Parallel Curriculum Model, and Kök and Davasligil (2014) in spatial thinking (cited in Erdoğan, 2017).

- When looking at the studies referring to student opinions in the use of the learning station technique, the research of Karacalı (2018) compiling the studies conducted in our country stands out; "According to these studies, students; They stated that they were able to express themselves better with activities based on the learning stations technique, the activities increased their desire to participate in the lesson, they were able to look at the lessons more critically and critically, they were able to adapt what they learned to daily life, the lessons were fun and this method should be continued. (Karacal1, 2018). Most of the opinions mentioned in this research were expressed by the students. In this context, it seems positive that the differentiation of lessons by using the learning station technique contributes to gifted students to learn science concepts more effectively. 


\section{Suggestions}

This research was conducted with four gifted fifth grade students. It may be repeated with the participation of more students to contribute to viewing problems of gifted students from a wider perspective.

\section{Suggestions for Teachers}

Teachers with gifted students in their classes can apply more active methods such as demonstration experiments, modeling or learning stations beside plain explanation in order to prevent the students from getting bored and to increase performance. It should be the duty of science teachers to replicate natural events through modeling or different experiments so that the students can experience how these events occur in the nature.

\section{Suggestions for Curriculum Developers}

Interviews and earth science journals revealed that the students were not as active as they wanted to be in the lessons at their schools. In addition, concepts which they can actually learn quite easily become boring for them due to inadequate or insufficient teaching methods (such as plain explanation). All these factors result in gifted students seeking education in special institutions focusing on these issues. The main task for curriculum developers is to develop programs which enable students to conduct lessons without getting bored and to actively take part in the process.

\section{Acknowledgement}

Mrs. Cansu Aldemir, who is the director of the Bursa / PUYED, supported the implementation of this study in PUYED as part of the "science" course. In addition, she prepared an ethical consent to be given to parents for gifted students to take part in this research and took initiative in this regard. We would specifically like to thank her for all her efforts.

We also sincerely thank the gifted students Deniz, Tuğba, Berrak, and Eymen who actively took part in the research. 


\section{Statements of ethics and conflict of interest}

"I, as the Corresponding Author, declare and undertake that in the study titled as "Evaluation of Learning Stations on Earth Science Concepts by Gifted Students: Bursa PUYED Example", scientific, ethical and citation rules were followed; Turkish Online Journal of Qualitative Inquiry Journal Editorial Board has no responsibility for all ethical violations to be encountered, that all responsibility belongs to the author/s and that this study has not been sent to any other academic publication platform for evaluation."

\section{References}

Akkaş, E., \& Tortop, H. S. (2015). Üstün yetenekliler eğitiminde farklılaştırma: temel kavramlar, modellerin karşılaştırılması ve öneriler. Üstün Zekâlılar Eğitimi ve Yaratıcılık Dergisi, 2(2), 31-44.

Arslan, A. \& Doğru M. (2014). Modellemeye dayalı fen öğretiminin ilköğretim öğrencilerinin anlama, hatırda tutma, yaratıcılık düzeyleri ile zihinsel modelleri üzerine etkisi. Akdeniz Insani Bilimler Dergisi, 4 (2), 1-17.

Beckman, M. (1990). Collaborative learning: Preparation for the work place and democracy. College Teaching, 38, 128- 133.

Bekereci, Ü., Şimşek, F., Hamzaoğlu, E., \& Yazici, M. (2020). Fen bilimleri dersinde istasyon tekniği kullanımının öğrencilerin akademik başarılarına ve fen tutumlarına etkisi. Anemon Muş Alparslan Üniversitesi Sosyal Bilimler Dergisi, 8(6), 1779-1786.

Benek, İ., \& Kocakaya, S. (2012). İstasyonlarda öğrenme tekniğine yönelik öğrenci görüşleri. Ĕgitim ve Öğretim Araştırmaları Dergisi, 1(3), 8-18.

Benek, İ., \& Kocakaya, S. (2016). İstasyon tekniğinin öğrencilerin fen ve teknoloji dersindeki başarılarına etkisi. Fen Bilimleri ve Matematik Eğitimi Kongresi, 28-30.

Benek, İ. \& Kocakaya, S. (2017). İstasyonlarda öğrenme tekniği. In B. Akçay (Ed.), Fen bilimleri ĕgitimi alanındaki öğretme ve ögrenme yaklaşımları (pp. 75-85). Ankara: Pegem Akademi Yayınları.

Bilgiç, N., Taştan, A., Kurukaya, G., Kaya, K., Avonoğlu, O., \& Topal, T. (2013). Özel yetenekli bireylerin eğitimi strateji ve uygulama kllavuzu [Training strategy and 
implementation guide for gifted and talented individuals]. Ankara: Millî Eğitim Bakanlığı Özel Eğitim Hizmetleri Genel Müdürlüğü.

Bralower, T. J., Feiss, P. G., \& Manduca, C. A. (2008). Preparing a new generation of citizens and scientist to face earth's future. Liberal Education, 94 (2), 20-23.

Bulunuz, N. \& Jarrett, O. (2006). Basic earth and space science concepts: building elementary teacher understanding. Paper presented at the annual conference of the "Georgia Science Teachers Association”, Columbus, Georgia.

Bulunuz, N. \& Jarrett, O. S. (2009). Understanding of earth and space science concepts: strategies for concept-building in elementary teacher preparation. School Science and Mathematics, 109 (5), 276-289.

Bulunuz, N. \& Jarrett, O. S. (2010). The effects of hands-on learning stations on building American elementary teachers' understanding about earth and space science concepts. Eurasia Journal of Mathematics, Science and Technology Education, 6 (2), 85-99.

Burns, D. (1993). A six-phase model for the explicit teaching of thinking skills. Storrs, CT: University of Connecticut, National Research Center on the Gifted and Talented.

Clement, M., \& Vandenberghe, R. (2000). Teachers' professional development: a solitary or collegial (ad) venture?. Teaching and teacher education, 16(1), 81-101.

Collins, A. \& Spiegel, S.A. (2001). Teacher research, http://www.enc.org/professional/research/journal/science/documents.

Cohen, E. G. (1994). Restructuring the classroom: Condition for productive small groups. Review of Educational Research, 64(1), 1- 35.

Cohen, L. \& Mannion, L. (1998). Research methods in education. 4. Bask1, London: Routledge Press.

Creswell, J. W. (1994). Research design: Qualitative and quantitative approaches. Thousand Oaks, CA: SAGE Publications.

Çakmak, M. (2018). Istasyon tekniğinin 6. sınıf madde ve ısı ünitesindeki öğrenci başarısına etkisi ve ögrencilerin tekniğe ilişkin görüşleri. (YayımlanmışYüksek Lisans Tezi) Dicle Üniversitesi, Eğitim Bilimleri Enstitüsü, Diyarbakır.

Çelikdelen, H. (2010). Bilim sanat merkezlerinde bilim birimlerinden destek alan üstün yetenekli öğrencilerin kendi okullarında fen ve teknoloji dersinde karşılaştıkları güçlüklerin değerlendirilmesi. (Unpublished doctoral dissertation), Selçuk Üniversitesi, Konya.

Çepni, S. (2014). Araştırma ve Proje Çalışmalarına Giriş, (7. baskı). Trabzon 2011. 
Çepni, S., Gökdere, M. ve Küçük M. (2002). Zihinsel alanda üstün yetenekli öğrencilere yönelik Purdue Modeline dayall fen alaninda örnek etkinlik geliştirme, 5. Ulusal Fen ve Matematik Eğitimi Kongresi Bildiriler Kitabı, Ankara: Orta Doğu Teknik Üniversitesi, 69.73 .

Çepni, S., \& Çil, E. (2016). Fen bilimleri dersi öğretim programı (tanıma, planlama, uygulama ve teog ile ilişkilendirme) ilkokul ve ortaokul ögretmen el kitabı, 6. Baskı Pegem A Yayınc1lık, Ankara.

Düşkün, İ. \& Ünal, İ. (2015). Modelle öğretim yönteminin fen eğitimindeki yeri ve önemi. Mehmet Akif Ersoy Üniversitesi Ĕ̈itim Bilimleri Enstitüsü Dergisi, 4(6), 1-18.

Erdoğan, S. C., \& Kahveci, N. G. (2015). Farklılaştırılmış fen ve teknoloji öğretiminin üstün zekalı ve yetenekli öğrencilerin tutumlarına etkisi [The effect of differentiated science and technology instruction on gifted and talented students' attitude]. Hayef: Journal of Education, 12(1), 191-207.

Erdoğan, S. C. \& Kahveci, N. G. (2017). Fen eğitiminde üstün zekâlı (özel yetenekli) öğrenciler için farklılaştırılması. In B. Akçay (Ed.), Fen bilimleri eğitimi alanındaki öğretme ve öğrenme yaklaşımları (pp. 109-128). Ankara: Pegem Akademi Yayınları.

Erdağı, S. (2014). İstasyon tekniğinin fen ve teknoloji dersinin akademik başarısına etkisi. Yayınlanmamış Yüksek Lisans Tezi, Kafkas Üniversitesi, Kars.

Erdağı, S. \& Önel, A. (2015). İstasyon tekniğinin uygulandığı fen ve teknoloji dersine ilişkin öğrenci görüş ve performanslarının değerlendirilmesi. e-Kafkas Ĕ̆itim Araştırmaları Dergisi, 2(1).

Fraling, C. (1982). A study to improve compehension skills through the study of prepared reading learning stations. Doktora tezi, the Union For Experimenting Colleges and Universities, USA.

Gagné, F. (2000). A differentiated model of giftedness and talent (DMGT). Systems and models for developing programs for the gifted and talented, 2.

Gobert, J. D., \& Pallant, A. (2004). Fostering students' epistemologies of models via authentic model-based tasks. Journal of Science education and Technology, 13(1), 7-22.

Gould, J. C., Weeks V., \& Evans, S. (2003). Science starts early. Gifted Child Today, 26(3), $38-42$.

Güneş, E. (2009). Fen ve teknoloji dersinde istasyon tekniği ile yapılan öğretimin erişiye ve kalıcılı̆̆a etkisi. (Yayınlanmamış Yüksek Lisans Tezi). Hacettepe Üniversitesi, Sosyal Bilimler Enstitüsü, Ankara. 
Halkitis, P. N. (1990). A model of elementary school gifted science education. Gifted Child Today Magazine, 13(4), 12-16.

Heller, K. A. (1996). The nature and development of giftedness: A longitudinal study. Fostering the growth of high ability. European Perspectives, 41-56.

Jacobson, W. \& A.B. Bergman. 1980. Science for children: A book for teachers. Englewood cliffs, NJ: Prentice-Hall.

Jarrett, O. (2010). " Inventive" Learning Stations. Science and children, 47(5), 56.

Kanlı, E. (2011). Üstün zekali ve yeteneklilerin alan eğitiminde hizlandirma. HAYEF Journal of Education, 8(2), 95-104.

Karacalı, K. (2018). Fen öğretiminde öğrenme istasyonları konusunda Türkiye'de yapılan çalışmalardan bir derleme. ESTÜDAM Eğitim Dergisi, 3 (2), 59-77.

Kastens, K. A., \& Manduca, C. A. (Eds.). (2012). Earth and mind II: A synthesis of research on thinking and learning in the geosciences (Vol. 486). Geological Society of America.

Koca, M. (2018). Altıncı sınıffen bilimleri dersi hücre konusunun öğretiminde istasyon tekniği uygulamasının öğrencilerin akademik başarısına, kalıcılı̆̆ına ve tutumlarına etkisi. (YayımlanmışYüksek Lisans Tezi). Fırat Üniversitesi, Eğitim Bilimleri Enstitüsü, Elâzı ̆̆.

Kök, B., \& Davasligil, Ü. (2014). The effect of teaching geometry which is differentiated based on the parallel curriculum for gifted/talented students on spatial ability. Journal for the Education of Gifted Young Scientists, 2(1), 40-52.

Meador, K. S. (2003). Thinking creatively about science suggestions for primary teachers. Gifted child today, 26(1), 25-29.

McLelland, C. V. (2011). The Nature of science and the scientific method. Geological Society of America, 1-8.

MEB Yönergesi, (2015). Millî Ĕ̆itim Bakanlı̆̆l Bilim ve Sanat Merkezleri Yönergesi, Retrieved from https://orgm.meb.gov.tr/meb_iys_dosyalar/2015_09/18101802_bilimvesanatmerkezl eriynergesi.pdf.

Millî Eğitim Bakanlığı, (2018). Fen bilimleri öğretim programı. http://mufredat.meb.gov.tr/dosyalar/201812312311937fen $\% 20 \mathrm{~b} \% \mathrm{c} 4 \% \mathrm{~b} 01 \% \mathrm{c} 4 \% \mathrm{~b} 0 \mathrm{mler} \% \mathrm{c} 4 \% \mathrm{~b} 0 \% 20 \% \mathrm{c} 3 \% 96 \% \mathrm{c} 4 \% 9 \mathrm{eret} \% \mathrm{c} 4 \% \mathrm{~b} 0 \mathrm{~m} \% 20 \mathrm{pr}$ ogramı2018.pdf 'den alınmıştır. 
MEB (2019). PISA 2018 Türkiye ön raporu. Ankara: http://pisa.meb.gov.tr/wpcontent/uploads/2020/01/PISA_2018_Turkiye_On_Raporu.pdf

Mısır, M. E., Muğaloğlu, E. Z. \& Dal, B. (2017). Yerbilim okuryazarlığı. In Akçay, B., Fen bilimleri ĕgitimi alanındaki öğretme ve öğrenme yaklaşımları (pp. 241-251). Ankara: Pegem Akademi Yayınları.

Michigan State Board of Education (2006). High school content expectations: Earth science. Retrieved from https://www.michigan.gov/documents/Earth_HSCE_168206_7.pdf.

Naglieri, J. \& Das, J. P. (1997). Cognitive assessment system administration and scoring manual. Itasca, Illinois: Riverside Publishing.

Newberry, M., \& Gilbert, J. K. (2007). Bringing learners and scientific expertise together. In Science education for gifted learners (pp. 213-227). Routledge.

Ngoi, M. \& Vondracek, M. (2004). Working with gifted science students in a public high school environment. Journal of Secondary Gifted Education, 15(4), 141-147.

OECD (2019a). PISA 2018 assessment and analytical framework. Paris: OECD Publishing. doi:https://doi.org/10.1787/b25efab8-en

Öktem, F., Gençöz, T., Erden, G., Sezgin, N. \& Uluç, S. (2013). Wechsler çocuklar için zekâ ölçeği IV (WÇZÖ-IV) uygulama ve puanlama el kitabı türkçe sürümü. Türk Psikologlar Dergisi, Ankara.

Özyaprak, M., \& Davasligil, Ü. (2015). The effectiveness of a math differentiation program for gifted students on math attitude. Journal of Gifted Education Research, 3(2), 2647.

Renzulli, J. S. (1978). What makes giftedness? Reexamining a definition. Phi Delta Kappan, $60(3), 180$.

Renzulli, J. S., \& Reis, S. M. (1985). The schoolwide enrichment model: A comprehensive plan for educational excellence. Creative Learning Press.

Renzulli, J. S. (2016). The three-ring conception of giftedness. In S. M. Reis (Ed.). Reflections On Gifted Education (pp. 55-86). Waco, TX: Prugrock Press.

Roberts, J. L. (2005). Enrichment opportunities for gifted learners. Retrieved from https://books.google.com.tr/books?hl=tr\&lr=\&id=lb7EI3tJkjkC\&oi=fnd\&pg=PA2\& $\mathrm{dq}=$ Roberts, + J. + L. $+(2005) .+$ Enrichment + opportunities + for + gifted + learners. + Prufro ck + Press + Inc.\&ots $=$ FfZ_SaTqoP\&sig $=$ Cu3k2BjkHvIXDOGwoMw6Hi3BTk\&redir_esc $=y \# v=$ onepage $\& q=$ Roberts $\% 2 C \% 20 J . \% 20 L . \% 2$ 
0(2005).\%20Enrichment\%20opportunities\%20for\%20gifted\%20learners.\%20Prufro ck\%20Press\%20Inc. \&f $=$ false

Sak, U. (2014). Üstün zekalılar özellikleri tanılanmaları ĕgitimleri. Ankara: Vize Yayıncılık.

Sak, U. (2017). Üstün zekâlılar: özellikleri, tanılanmaları, eğitimleri. Ankara: Vize Akademi.

Savaşır, I. \& Şahin, N. (1995). Wechsler çocuklar için zekâ ölçeği uygulama kitapçığı. Türk Psikologlar Derneği, Ankara.

Seel, N. M. (2001). Epistemology, situated cognition, and mental models: 'Like a bridge over troubled water'. Instructional science, 29(4-5), 403-427.

Sternberg, R. J. (1993) The concept of "giftedness": a pentagonal implicit theory. The origins and development of high ability içinde, CIBA Foundation Symposium Series, Chichester: John Wiley and Sons, 5-21.

Sternberg, R. J., \& Zhang, L. F. (1995). What do we mean by giftedness? A pentagonal implicit theory. Gifted Child Quarterly, 39(2), 88-94.

Talim ve Terbiye Kurulu Başkanlığı. (2017). Müfredatta yenileme ve değişiklik çalışmalarımız üzerine. $\quad$ Retrieved from https://ttkb.meb.gov.tr/meb_iys_dosyalar/2017_07/18160003_basin_aciklamasiprogram.pdf.

The Geological Society of America [GSA]. (2011). The Importance of Teaching Earth Science. Retview from https://www.geosociety.org/documents/gsa/positions/pos4_TeachingEarthScience.pdf

Tomlinson, C. A. (1999). The Differentiated Classroom: Responding to the Needs of All Learners. Alexandria, VA: Association for Supervision and Curriculum Development

Tomlinson, C.A., Kaplan, S.N., Renzulli, J.S., Leppien, J., Burns, D. \& Purcell, J. (2002): The Paralel Curriculum: A Design to Develop High Potential and Challenge High Ability Learners. USA: Corwin Pres, INC.

Tomlinson, C. A. \& Strickland, C. A. (2005). Differentiation in practice a resource guide for differentiating curriculum.Alexandria, Virginia USA: Association for Supervision and Curriculum Development.

Tortop, H. S. (2015). Üstün zekâlılar eğitiminde farklılaştırılmış öğretim; müfredat farklılaştırma modelleri. Ankara: Gen Bilge Yayıncılık. 
Türkman, B. (2017). Genel eğitim programını özel yetenekli öğrencilerin ihtiyaçlarına göre farklılaştırma stratejileri? S. Emir içinde, Özel yeteneklilerin eğitiminde program tasarımı (ss. 25-43). Ankara: Pegem Akademi.

Ülger, B. B. (2020). The development, implementation and effect of differentaited inquirybased science lesson modules for gifted students. Doctoral dissertation, Uludağ University, Turkey. VanTassel-Baska, J., \& Stambaugh, T. (2006). Comprehensive curriculm for gifted learneres. Pearson Education. Boston.

VanTassel-Baska, J., \& Brown, E. F. (2007). Toward best practice: An analysis of the efficacy of curriculum models in gifted education. Gifted Child Quarterly, 51(4), 342-358

White, J.R. (2005). Empty lots as modern classrooms. (In Ed. S. K. Johnsen and J. Kendrick), Science education for gifted students, 0Prufrock Pres, Inc., USA. 